\section{S0SIAfLL- Lä̈̈HETIETEELLINEW AIHAHAUSLEHTI}

Journal of Sogial Medicine

Päätoimittaja

Sari Räisänen

editor@socialmedicine.fi

Toimitussihteeri

Suvi Määttä

Puh. 0405937048

toimitussihteeri@ socialmedicine.fi

Toimitusneuvosto

Anssi Auvinen, Heikki Hiilamo, Ilmo Keskimäki, Leena Koivusilta, Simo Kokko, Pekka Louhiala, Esa Läärä, Sami Pirkola, Ossi Rahkonen, Arja Rimpelä, Eva Roos, Sirkka Sinkkonen ja Päivi Topo

Julkaisija

Sosiaalilääketieteen yhdistys ry

Socialmedicinska föreningen rf

Puheenjohtaja

Peija Haaramo

Terveyden ja hyvinvoinnin laitos

PL 30

0027I Helsinki

\author{
Sihteeri \\ Sanni Helander \\ Suomen Syöpärekisteri \\ Unioninkatu 20-22 \\ 00120 Helsinki \\ sihteeri@socialmedicine.fi \\ Neljä numeroa vuodessa \\ Tilaushinnat vuonna 2017: \\ Jäsenet $45 €$, opiskelijat $20 €$ \\ (Sosiaalilääketieteen yhdistyksen jäsenmaksu) \\ Muut, yhteisöt ja tilaukset ulkomaille $50 €$, \\ irtonumerot $13 €+$ postikulut
}

ISSN 0355-5097

Kirjapaino Hermes Oy 2017

\title{
Sanoista teoiksi \\ - Miten maahanmuuttoon liittyvä terminologia luo todellisuutta ympärillämme?
}

Tämä Sosiaalilääketieteellisen aikakauslehden teemanumero ulkomaalaistaustaisista käsittelee monia tämän päivän Suomen maahanmuuttoon liittyviä kiinnostavia ja tärkeitä ajankohtaisia kysymyksiä. Onnittelen julkaisun toimitusta relevantin yhteiskunnallisen aiheen valinnasta, toimituskuntaa hienosta kirjoituskokoelmasta ja kirjoittajia akateemisesti arvokkaista teksteistä ja puheenvuoroista. Tätä pääkirjoitusta kirjoittaessani huomaan kuitenkin miettiväni eniten kysymyksistä perinteisempiä: retoriikkaan liittyviä haasteita ja toisaalta myös mahdollisuuksia. Tähän vähintäänkin inspiroi tässä lehdessä oleva väitöskirjatutkija Raskin puheenvuoro rapakon takaisista tunnelmista.

Niin tutkija kirjoittaessaan, asiantuntija esitelmöidessään, ammattilainen työssään, kuin kansalainenkin jutustellessaan tekee jatkuvasti miljoonia kannanottoja valitessaan sen kielen ja ne sanat joita käyttää. Nämä valinnat voivat olla vaikutuksiltaan suurempia kuin mitä äkkiseltään tulemmekaan ajatelleeksi.

Tieteenfilosofian sosiaalisen konstruktivismin näkemyksen mukaan todellisuus on meidän ihmisten itsemme luoma, ja se tulee luoduksi siinä kielessä mitä mielensisäisesti ja sosiaalisissa vuorovaikutustilanteissa käytämme. Todellisuus ei siis ole mikään absoluuttinen, meille annettu heijastuma maailmasta, vaan jotakin sellaista mitä me itse aktiivisesti luomme. Voimme siis itse vaikuttaa siihen, millaisessa todellisuudessa elämme. Esimerkiksi psykoterapian teorianmuodostuksessa kielen merkityksestä todellisuuden 
luojana on kirjoitettu jo vuosikymmeniä: ihmisen hankalan elämäntilanteen sanoittaminen vaikkapa "jumissa olemiseksi" taikka "elämän tärkeässä tienhaarassa olemiseksi” voi herättää varsin erilaisen määrän toiveikkuutta ja toipumisen mahdollisuutta, vaikka elämäntilanne ei sinänsä, absoluuttisessa mielessä erilaisen ilmaisun myötä muuttuisikaan.

Siirtyessämme temaattisesti lähemmäs tämän lehden aihetta eräs hyvä esimerkki käyttämämme kielen voimasta voisi olla vaikkapa vanhemman käsitteen "kehitysapu" ainakin osittainen retorinen päivittäminen "kehitysyhteistyöksi". Joku voi, ehkäpä jossain määrin aiheellisestikin, kritisoida tätä näennäisenä, kielellisenä pelinä vailla todellisia sisällöllisiä muutoksia. Konstruktivisti puolestaan näkisi, että muuttaessamme käyttämäämme terminologiaa, myös toimintamme sitä kautta muuttuu sisällöllisesti sanojemme mukaiseksi, eli yksisuuntaisesta avusta kaksisuuntaiseksi yhteistyöksi. Mikäli siis huomaamme itsessämme osan konstruktivistia, niin meitä kiinnostaa se, millaisen todellisuuden muodostamme käyttämällämme kielellä vaikkapa maahanmuuttajuuden ympärille.

Käsitteen "toisen sukupolven maahanmuuttaja" ongelmallisuus on puhuttanut asiaan vihkiytyneitä jo vuosia, sillä, kuten Rask kirjoittaa, käsitteellä osoitettu henkilö on ensisijaisesti Suomessa ja vähintään osittain suomalaisuuteen syntynyt ja kasvanut, eikä edes maasta toiseen muuttanut. Käsite kuitenkin esiintyy yhä kirjallisuudessa, kenties siksikin, että vakiintuneen termin tilalle uuden sopivan löytämiseen saattaa liittyä monia käytännön hankaluuksia. Parempia ehdokkaita ovat olleet muun muassa "ulkomaalaistaustainen" tai "ulkomaista syntyperää oleva", jotka adekvaatisti osoittavat kirjoittajan huomioivan taustaisuuteen liittyvän problematiikan. Itse uskaltauduin ensimmäistä kertaa vasta viime vuonna käyttämään kirjoitetussa tekstissä kilpailevaa määrettä "ensimmäisen sukupolven suomalainen" (lainaten "first generation american" -mallia), enkä edelleenkään ole varma, mikä ilmaisu olisi paras. Linjan muuttaminen ja kantaaottavasti vastoin totutun tekeminen herättää helposti epävarmuutta, mutta ehkä se silti kannattaa.

Myös ulkomaalaistaustaisten vertailussa muihin suomalaisiin, suomalaistaustaisiin tai koko väestöön sanavalinnat värittävät kirjallisuut- tamme. Tästä maahanmuuttajien vertailukohtana olevasta väestöstä tai tutkimusjoukosta käytetään joskus termiä "valtaväestö", joka on monin tavoin ongelmallinen asettaessaan ulkomaalaistaustaiset lähtökohtaisesti vallan ulkopuolelle tai unohdettaessa, että muuhunkin väestöön sisältyy useita erilaisia haavoittuvassa asemassa olevia ryhmiä ja vähemmistöjä.

Eräs retorinen valinta, joka on lähiaikoina puhututtanut alan toimijoita Suomessa, liittyy "paperittomuuteen" tai "laittomuuteen". Kuusio, Nykänen ja Keskimäki ovat tämän lehden artikkelissa valinneet puhuttavan "paperittomista”. Pidän suurena ja epäsuotuisana kannanottona esimerkiksi valtiovallan edustajilta sitä, että joissain yhteyksissä on alettu käyttää suhteellisen vakiintuneen ja neutraalin "paperiton" käsitteen sijaan käsitettä "laiton maahanmuuttaja". Siinä todellisuudessa, jonka minä haluan ympärilleni konstruoida, ei yksikään ihminen ole "laiton".

Kunniaväkivalta on eräs retoristen valintojen kannalta kiinnostava teema, vaikka liittyykin vain hyvin pieneen ulkomaalaistaustaisten marginaalijoukkoon. Käsitettä "kunniaväkivalta" on tuoreemmin alettu ilmaista myös "kunniaan liittyvänä väkivaltana", jolla halutaan viestittää, että kyseisessä väkivallassa ei ole mitään kunniakasta, vaikka se liittyykin kunnian menetyksen tematiikkaan. Olisimmeko kuitenkin valmiita alkamaan puhua mieluummin "häpeäväkivallasta" tai "häpeään liittyvästä väkivallasta"? Oleellisempaahan on, että väkivallantekijä kokee vahvaa häpeän tunnetta, tuota tunteista yhtä vaikeimpia, ja nimenomaan hänen häpeänsä ohjaa häntä toimimaan väkivaltaisesti, eikä toisen kunniattomuus sinänsä.

Viime aikoina olen myös tullut pohtineeksi asiantuntijakirjoituksissamme sanan "kotimaa" käyttöä puhuessamme Suomeen muuttaneiden ihmisten synnyinmaista. Tämä ymmärrettävästi viitaa joskus asianosaisten omaankin kokemukseen siitä, että synnyinmaa tulee aina olemaan sydämessä oleva kotimaa. Tulemmeko kuitenkin sanavalinnoillamme osittain tahtomattammekin sanoneeksi "sun koti ei oo täällä"? Jos alkaisimme enemmän puhua Suomesta maahamme tulleiden maahanmuuttajien kotimaana, niin voisiko se myös Suomeen muuttaneista alkaa helpommin tuntua siltä?

Rask problematisoi kirjoituksessaan myös sitä, mitä saattaa tapahtua, mikäli painotamme 
puheissamme ja toimissamme vain ihmisten välistä samankaltaisuutta ja yksilöllisyyden korostamisen hyvässä tarkoituksessa ummistamme silmämme vaikkapa etnisten taustojen mahdollisilta vaikutuksilta. Tällöin saatamme tahtomattamme ohittaa vuosisatoja kestäneen rasismin ja länsimaisen tavan potkaista kehittyvät maat pois kehityksen tikapuilta oman edun nimissä ("kicking away the ladder"), ja näiden seurauksena syntyneet yhteiskunnalliset eriarvoisuudet.

Pahimmillaan tämä johtaisi siihen, että tukea tarvitsevat ihmiset eivät sokeuttamme saisi apua esimerkiksi palvelujärjestelmältämme, vaikka useissa tämänkin teemanumeron kirjoituksissa tuodaan esiin sellaisia erityispiirteitä tai -tarpeita, joita terveys- ja sosiaalipalveluissa tulisi ottaa huomioon ulkomaalaistaustaisten asiakkaiden neuvonnassa ja hoidossa sekä ulkomaalaistaustaisen lääkärien, muun henkilöstön ja monikulttuuristen työyhteisöjen osalta. Voisimmeko siis pyrkiä samaan aikaan toisaalta ylläpitämään ajatusta maahanmuuttajien mahdollisista erityis- piirteistä tai -tarpeista, jotka liittyvät vaikkapa kieleen, taustaan tai kulttuuriin, ja samaan aikaan toisaalta pitämään toimintamme johtotähtenä sitä, että loppupeleissä ensiarvoista on aina yksilöllinen kohtaaminen ja että yksinkertaisesti "ihminen on ihmiselle ihminen"?

Tämän teemanumeron aihepiirin tutkimus on viime vuosina vilkastunut Suomessa, ja onkin selvää, että tarvitsemme yhä enemmän tutkimustietoa esimerkiksi palvelujärjestelmän kehittämisen, kuten sote-uudistuksen, perustaksi. Weiste-Paakkanen ym. kirjoituksessaan osoittavat, että on tärkeää suunnitella ja toteuttaa tutkimustiedonkeruu laadukkaasti ja niin, että ulkomaalaistaustaisten erityistarpeet ja osallisuus tulevat huomioiduiksi. Teemanumero avaa toivottavasti lukijoilleen uusia näkökulmia ja nostaa esiin uusia tutkimuskysymyksiä ja kehittämistarpeita.

\section{Anu Castaneda}

Tutkimuspäällikkö

Terveyden ja hyvinvoinnin laitos 